\title{
Optimisation of DNA extraction from rumen bacteria
}

\author{
L Broudiscou 1, H Geissler 1, A Broudiscou 2 \\ IINRA, Nutrition des Herbivores, Theix, 63122 St-Genès-Champanelle ; 2 LMRE, Université \\ d'Aix-Marseille III, 13013 Marseille, France
}

\begin{abstract}
One major condition for estimating rumen bacteria growth rate by ${ }^{32} \mathrm{P}$ incorporation into DNA is the use of a DNA extraction procedure which produces a non selective lysis of cells and gives a high DNA recovery rate. The aim of this study was to adapt a freeze-thaw procedure used in soil biology (Tsai and Olson, 1991, Appl Environ Microbiol, 57, 1070-1074) to the treatment of mixed rumen bacteria.
\end{abstract}

Six qualitative factors have been considered : the interest of an enzymatic pre-treatment - by proteinase $\mathrm{K}$ (concentration of $0.5 \mathrm{~g} / \mathrm{l}$ ) or lysozyme (concentration of $5 \mathrm{~g} / \mathrm{l}$ ) - and the use of five detergents - CHAPS, sodium deoxycholate, SDS, Triton X-100 and sodium lauroyl sarcosine (SLaS). In order to screen efficiently these factors, an asymmetric design of 9 runs was generated among the 96 available combinations of factors and it was applied in duplicate. The characteristics of this design are satisfactory (number of experiments $=18 ; \mathrm{Log}$ determinant $(M)=-4.60$; maximal variance function $=0.47 ; G$ efficiency $=94 \%$ ). The worksheet is available from the authors. The bacterial pellets obtained by centrifugation $(27,000 \mathrm{~g}, 30 \mathrm{~min}$.) were incubated in $300 \mu \mathrm{l}$ of enzymatic lysis buffer at $37^{\circ} \mathrm{C}$ for $1 \mathrm{~h}$. Then $400 \mu$ of detergent solution (TE, pH 8.5) was added and a cycle of freezing at $-20^{\circ} \mathrm{C}$ for $30 \mathrm{~min}$ and thawing at $37^{\circ} \mathrm{C}$ for $30 \mathrm{~min}$ was conducted. All the detergents but SlaS were screened at their critical micellization concentration (CHAPS : $5 \mathrm{mM}$, sodium deoxycholate : $4 \mathrm{mM}$, SDS : $2 \mathrm{mM}$, Triton $\mathrm{X}-100: 0.3 \mathrm{mM}$, SLaS : $17 \mathrm{mM}$ ). DNA was extracted using phenol \isoamyl alcohol \ chloroform and precipitated by addition of spermine. After removal of spermine, the DNA pellet was dissolved in $1 \mathrm{ml}$ of TE buffer (pH 8.0). Two responses have been measured. The proportion of lysed cells was estimated by acridine orange counts. The DNA recovery rate was measured by a fluorometric method using ethidium homodimer (Mordy and Carlson, 1991, Mar Ecol Prog Ser, 73, 283-293).

The main effects of the 6 factors were estimated by fitting a Free Wilson model. The parameter estimates of the simplified model and the Student's probabilities for testing the null hypothesis $(P>|T|)$ are given in the table. The results of the regression analysis were satisfactory (estimated experimental error of 1.45 and 0.92 , R-squared of 0.84 and 0.98 respectively for the proportion of lysed cells and the amount of recovered DNA). The use of lysozyme increased by $6 \%$ the proportion of lysed cells and by $45 \%$ the DNA recovery rate. As shown in the table, the two best detergents - SDS and SLaS - had smaller favorable effects. In conclusion, the enzymatic pretreatment with lysozyme and the use of both SDS and SLaS in the extraction buffer at the final concentration of $15 \mathrm{mM}$ were chosen.

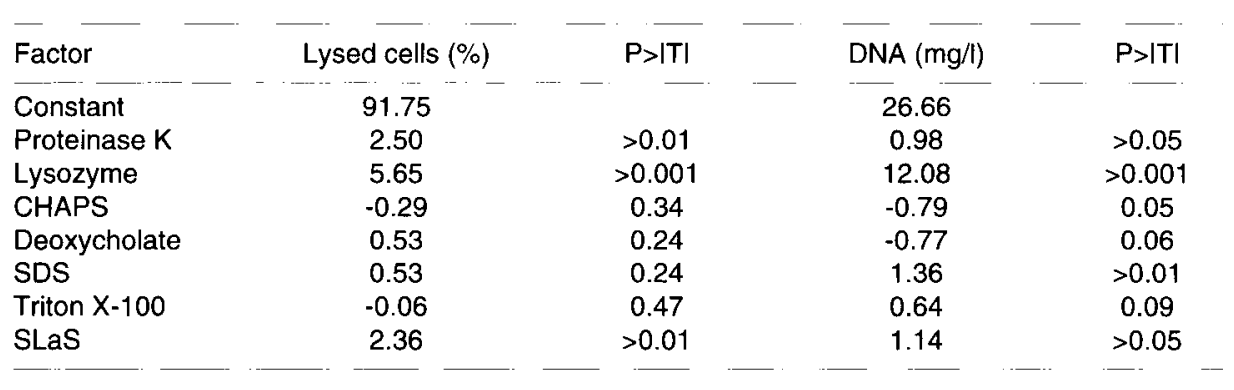

